Ks. Antoni ŻUREK

(Tarnów, PAT)

\title{
LAIKAT RZYMSKI W ŚWIETLE MÓW LEONA WIELKIEGO
}

Św. Leon Wielki, autor reprezentatywny dla rzymskiego Kościoła połowy V wieku, w swoich Mowach nie przedstawial kompleksowej „teologii laikatu”. Mimo to można tam znaleźć zarówno wypowiedzi ilustrujące jego zapatrywania na temat laikatu i jego miejsca w Kościele oraz roli, jaką on tam ma spełniać, jak też wiarygodne świadectwa sytuacji jaka w tym względzie miała miejsce w Kościele rzymskim. Temat ten pojawia się zwłaszcza w Mowach poświęconych rocznicy konsekracji św. Leona Wielkiego ${ }^{1}$. Zagadnienie to jest organicznie związane $z$ leoniańską wizją Kościoła oraz kapłaństwa, więc na ten kontekst należy zwrócić uwagę w pierwszej kolejności.

1. Członki „ciala Chrystusa”. Papieżowi bardzo bliska jest idea Kościoła jako ciała Chrystusa. Mówiąc o Kościele do rzymskich katolików św. Leon Wielki albo wprost mówi o „ciele, którego głową jest Chrystus”2, lub krócej o „ciele Chrystusa” 3 albo o „ciele Pańskim”. Tę samą ideę umie też wyrazić w sposób opisowy ${ }^{5}$. Te określenia są na tyle jasne, że Autor nie widzi specjalnej potrzeby ich dalszego wyjaśniania. Co najwyżej w Mowach stanowią one dla niego przesłankę do dalszych wniosków ${ }^{6}$. Określeń tych używa Papież na tyle często, że można je uważać za jego własne?.

${ }^{1}$ Chodzi o Sermones 92-96, SCh 200, 244-284, tłum. K. Tomczak, Poznań 1958, POK 24, 3-21. Wedlug J.P. Migne'a (PL 54, 141-156) i idącego za nim K. Tomczaka są to mowy 1-5. Autor stosuje przekład własny.

${ }^{2}$ Sermo 69, 7, SCh 200, 56: „corpus cui caput est Christus”.

${ }^{3}$ Zwrot "corpus Christi" pojawia się w różnych konfiguracjach, por. Sermo 66, 2, SCh 200, 34; 52,5 , SCh 74, 93; 95, 1, SCh 200, 266; 78, 2, SCh 200, 122; 76, 5, SCh 200, 108.

"Sermo 97, 4, SCh 200, 292: „corpus Dominicus".

${ }^{5}$ Por. wypowiedzi, gdzie Papież mówi o Chrystusie zasiadającym w chwale niebieskiej i nadal pozostającym w ścisłym związku z Kosciołem na ziemi, np. Sermo 59, 3, SCh 74, 131: „qui sedet ad dexteram Patris idem totius habitetur et corpus”; Sermo 60, 4, SCh 74, 138: „Christi ascensio, nostra provectio, quo praecessit gloria capitis, eo spes vocatur et corporis".

"Podobny wydźwięk ma określenie „ciało Kościoła”, np. Sermo 35, 1, SCh 49bis, 170: "Corpus Ecclesiae", lub też opisowe jego ujęcie. 
Gdy na Kościół patrzy się w kategoriach „ciała Chrystusa”, to wówczas na pierwszy plan wysuwa się jego duchowy wymiar. Jednocześnie określenie „ciało" nasuwa skojarzenie ze zrozumiałym dla wszystkich pojęciem organizmu. To zresztą suponuje św. Leon Wielki nazywając Chrystusa głową, a wszystkich ochrzczonych - członkami ciała Chrystusa ${ }^{8}$. Nadprzyrodzony charakter tego organizmu sprawia, że wszystkie - nawet najmniejsze - jego członki mają ścisły związek z Głową ${ }^{9}$. Nobilituje to wszystkie członki tego ciała. Patrząc na Kościół $\mathrm{z}$ takiej perspektywy mniej uwagi zwraca się na widzialną strukturę tego organizmu, natomiast dostrzeżone i wyeksponowane zostaje wewnętrzne jego życie oraz odniesienie poszczególnych członków do Chrystusa. Każdy przynależący do Kościoła staje się „członkiem ciała Chrys-

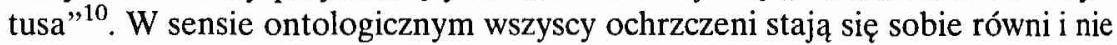
ma żadnego znaczenia, w którym miejscu „ciała Chrystusa” jest miejsce któregokolwiek $\mathrm{z}$ nich.

Ta równość, a jednocześnie godność, poszczególnych członków Kościoła znajduje swój wyraz w tytułach, jakimi św. Leon Wielki obdarza swoich słuchaczy. Zazwyczaj skierowane są do wszystkich wierzących, bez zaznaczania jakichkolwiek różnić między nimi. Są to tytuły odnoszące się do ogółu shuchaczy jego mów. Najczęściej przywołuje on godność wiernych, wynikającą z ich relacji z Bogiem ${ }^{11}$. Papież mówi zatem o „ludzie Bożym" ${ }^{2}$, „ludzie Chrystusa"13, „wierzących"14, „chrześcijanach”, niekiedy z przymiotnikiem ,katoliccy"15, „dzieciach Kościoła”, "ludach odrodzonych" "17. Są to najbardziej popularne w mowach określenia. Trudno na ich podstawie wywnioskować cokolwiek o roli, jaką świeccy mogli odgrywać w Kościele. Tytuły te wyrazają raczej szacunek kaznodziei do słuchaczy, u podstaw którego zauważyć należy świadomość godności słuchaczy, wynikającej $z$ ich ontycznego związku z Chrystusem.

${ }^{7}$ Byla to zresztą idea już dość popularna w patrologii łacińskiej V wieku, por. J.N.D. Kelly, Poczatki doktryny chrześcijańskiej, tłum. J. Mrukówna, Warszawa 1988, 306-309.

8 Por. Sermo 76, 5, SCh 200, 108: „membra corporis Christi”.

${ }^{9}$ Por. Sermo 95, 1, SCh 200, 264: "in Christo unum sumus (Gal 3, 28) nec quisquam ita est ab alterius divisus officio, ut non ad connexionem pertineat capitis cujuslibet humilitas portionis".

10 Por. Sermo 72, 2, SCh 200, 72: „membrum Christi”.

11 Pominąć należy w tym wypadku zwrot „dilectissimi”, który pojawia się - czasem nawet kilkakrotnie - w każdej Mowie.

12 Por. Sermo 22, 1, SCh 46, 34; 72, 1, SCh 200, 72: „populus Dei”; 75, 2, SCh 200, 92: ,potentissimus populus Dei”.

13 Por. Sermo 75, 4, SCh 200, 94: „populus Christi”.

14 Por. np. Sermo 96, 3, SCh 200, 280: „credentes” albo też Sermo 76, 4, SCh 200, 106; 79, 3 , SCh 200, 132: „fideles”.

15 Por. Sermo 1, 3, SCh 22, 72: „Christianus”; Sermo 66, 3, SCh 200, 36: „catholicus Christianus".

${ }^{16}$ Por. Sermo 81, 1, SCh 200, 142: „filii Ecclesiae”.

17 Por. Sermo 30, 3, SCh 49, 122: „omnes populi renatorum”. 
Jednak tak zrozumiała idea Kościoła jako „ciała” każe pomyśleć także „organach”, które spełniają określone funkcje, umożliwiające sprawne dzianie całego organizmu. Natura ciała zakłada nie tylko wielość członków, ale $z$ ich hicrarchię. Nie da się zaprzeczyć istnienia członków ważniejszych i mniej ażnych, bardziej dla całego organizmu niezbędnych i tylko potrzebnych. 'prawdzie sprawność działania całego organizmu zakłada sprawne funkcjojwanie wszystkich organów i komórek, ale nie przekreśla to wspomnianego óżnicowania i gradacji pod kątem ich niezbędności. Skoro $z$ natury rzeczy są organizmie funkcje ważniejsze i mniej ważne, to naturalną konsekwencją go podziału jest też wartościowanie na organy uchodzące za bardziej i mniej ıszczytne, bardziej i mniej niezbędne. W Mowach Leona Wielkiego wszystkie analogie znajdują swoje odzwierciedlenie.

Według tego Papieża „cały Kościół Boży [...] z różnych członków [się ladający] zachowuje jedność świętego ciała"18. Wspomniane zróżnicowanie łonków ma różnorodny charakter. Kaznodzieja w sposób oględny napomyka jednym z kazań o „bardzo wybitnych członkach” czy też wybitnych ${ }^{19}$, obok :órych dostrzega „bardzo skromnych”20. Można się tylko domyślać kryterium kiego podziału, które, jak się wydaje, nie ma waloru absolutnego. Być może zcydowały o tym kryteria moralne, skoro na tytul „wybornego członka Chrysเsa" zasługuje np. św. Wawrzyniec ${ }^{21}$. Podobnie mało wyraźny charakter ma ədzial na „wyższe” i „niższe” partie „ciała Kościoła”22. Jest to też rozróżniee bardzo ogólne, za którym możemy się tylko domyślać zróżnicowania wed$\mathrm{g}$ pełnionych funkcji. Zgodnie $\mathrm{z}$ tym rozróżnieniem, wspólnota dzieli się na kich, którzy pełnią bardziej odpowiedzialne funkcje i takich, którzy nie odywają w niej istotniejszej roli.

Św. Leon Wielki zna też bardziej konkretne zróżnicowania w ciele Chrysısa. Tak jak w każdym dobrze zbudowanym organizmie, tak też w organizmie ościoła różnorodne członki spełniają przypisane im funkcje. Jest to więc strukra zorganizowana. Tym co różnicuje członki są stopnie (gradus) i urzędy Ifficia). W jednym ze swych kazań Papież wprost powie o Kościele uporządkoanym według "stopni” i pełnionego "urzędu"23. Wprawdzie tylko niektóre tych stopni i urzędów zostaną w Mowach bezpośrednio wspomniane, ale ich tnienie nie podlega wątpliwości. Wśród tych funkcji z całą pewnością należy ymienić biskupstwo, a w sensie ogólniejszym - wszystkich kierujących Kościo-

\footnotetext{
${ }^{18}$ Por. Sermo 95, 1, SCh 200, 264: „ex diversis membris sacrati corporis subsitat integritas”.

19 Por. „electissima membra Christi” Sermo 72, 2, SCh 200, 72; „membra excellentissima rporis Christi" Sermo 93, 2, SCh 200, 250.

${ }^{20}$ Por. Sermo 95, 1, SCh 200, 264.

${ }^{21}$ Por. Sermo 72, 2, SCh 200, 72.

22 Por. Sermo 95, 1, SCh 200, 266: „superiora” i ,inferiora”.

${ }^{23}$ Por. Sermo 95, 1, SCh 200, 264: „universa Ecclesia Dei distinctis ordinata sit gradibus", którym to Kościele „quisquam ab alterius divisus est officio".
} 
$ł^{24}$. „Urząd biskupi”25 należy do najważniejszych, a ten pełniony przez Papieża jest „najwyższym stopniem”26. Jak widać, istnieje związek między stopniami a pełnionymi funkcjami. Można nawet mówić o istnieniu „stopni urzędów”27. Równość chrześcijan wynikająca z przynależności do ciała Chrystusa i zróżnicowanie ze względu na pełnione w tym ciele funkcje nie są jedyną perspektywą z której można oceniać miejsce poszczególnych wiernych w Kościele.

2. „Naród kapłański”. Z przynależności do „ciała Chrystusa” wynika specjalna godność wszystkich wierzących. Jest nią uczestnictwo w Chrystusowym kapłaństwie. Opierając się na tekście z 1 Listu św. Piotra o kapłaństwie królewskim (1 P 2,5), św. Leon Wielki z całą stanowczością przypomina: „wszystkich odrodzonych w Chrystusie znak krzyża czyni królami, namaszczenie Ducha Świętego konsekruje na kapłanów”28. Dzięki czemu „pomijając ową specjalną posługę naszej służby, wszyscy uduchowieni i myślący chrześcijanie niech poznają, że są z królewskiego rodu i uczestnikami urzędu kapłańskiego"29.

Wielkiemu Papieżowi, jak widać, bardzo bliska jest idea powszechnego kapłaństwa wszystkich wiernych. Na mocy namaszczenia - już w chwili chrztu - staje się ono udziałem każdego ochrzczonego. To namaszczenie ma charakter swoistej „konsekracji”, której dostępuje chrześcijanin. Na jej podstawie ochrzczony uczestniczy w ,,jednym sakramencie Najwyższego Kapłana" ${ }^{30}$. Jest to kapłaństwo jedyne i najwyższe. Ostatecznie tylko Chrystus jest „wszechmogącym i wiecznym Kapłanem”31, „najwyższym Arcykapłanem”32. Choć św. Leon Wielki tego specjalnie nie wyjaśnia, to można się domyśleć, że istotą tego kapłaństwa jest unikalna ofiara złożona przez Chrystusa.

Chrześcijanin stając się uczestnikiem kapłaństwa Chrystusa w tej ofierze w jakiś sposób bierze udział. Już samo to uczestnictwo powinno być dla każdego ochrzczonego „powodem wspólnej radości” ${ }^{33}$. Każdy jednak ma możliwość

${ }^{24}$ Sw. Leon Wielki nazywa ich ,rectores” (Sermo 94, 1 SCh 200, 266), albo „principes Ecclesiae" (Sermo 95, 3, SCh 200, 270).

25 Por. Sermo 93, 2, SCh 200, 250: „officium episcopale”.

${ }^{26}$ Por. Sermo 93, 1, SCh 200, 248: „summus gradus”. Ze słbw św. Leona Wielkiego nie wynika jednak, czy mówiąc o najwyższym stopniu, na który zostal wybrany ma na myśli biskupstwo, czy też urząd biskupa Rzymu, następcy św. Piotra.

27 Por. Sermo 96, 1, SCh 200, 278: „gradus officiorum".

28 Por. Sermo 95, 1, SCh 200, 266.

29 Por. tamże: „Omnes enim in Christo regeneratos, crucis signum efficit reges, Spiritus sancti unctio consecrat sacerdotes: ut praeter istam specialem nostri ministerii servitutem, universi spiritales et rationabiles Christiani agnoscant se regii generis, et sacerdotalis officii esse consortes".

${ }^{30}$ Por. tamże: „unum sacramentum Pontificii”.

31 Por. Sermo 94, 2, SCh 200, 256: „omnipotens et perpetuus Sacerdos”.

32 Por. Sermo 96, 3, SCh 200, 280: "Pontifex summus".

33 Por. Sermo 95, 2, SCh 200, 266: „de consortio istius muneris magna sit nobis materia communium gaudiorum". 
i obowiązek wypełnienia tego urzędu w sposób dla siebie właściwy. Papież Leon wyjaśnia to rzymskim katolikom w sposób bardzo przystępny:

„Cóż jest bardziej kapłańskiego niż ślubować Panu czyste sumienie i składać na ottarzu swego serca nieskalaną ofiarę pobożności"34.

Tego typu ofiary mogą i powinni składać wszyscy ochrzczeni. Na tej plaszczyźnie wszyscy ochrzczeni są sobie równi, zaś każdy z nich stawać się może równocześnie ofiarą i świątynią Boga ${ }^{35}$. W tym jednym kapłaństwie można jednak, jak się okazuje, uczestniczyć na różne sposoby, w zależności od stopnia.

Uświadomiwszy wiernym ich wielką godność wynikającą z faktu uczestniczenia wszystkich ochrzczonych w kapłaństwie Chrystusa, nasz Papież dodaje, że sakrament ten, ,dzięki rozlaniu się namaszczenia błogosławieństwa, spłynął bardziej obfity na wyższe [partie ciała Kościola], a na niższe, chociaż nie skąpo, to jednak relatywnie mniej obficie" ${ }^{36}$. Nietrudno się domyśleć, że w tej bardzo oględnej wypowiedzi chodzi o zauważenie różnicy między kapłaństwem wszystkich wiernych, a kapłaństwem tych, którzy pełnią „specjalną posługę sluzby", jak to jest w przypadku samego Leona Wielkiego ${ }^{37}$. Istnieje zatem różnica stopnia, która nie wynika $z$ czysto mechanicznego zabiegu, ani też z formalnej nominacji. Ma ona swoje źródło i uzasadnienie w czynności sakralnej (unctio), za którą stoi działanie łaski. Sam Papież potwierdza to w innej ze swych mów. Wyjaśniając wiernym istotę swego biskupiego urzędu, ukazuje najpierw jego analogie w Starym Testamencie, gdzie urząd kapłański Aarona był dziedziczny, dodając:

„Kościół otrzymuje tych rządców, których Duch Święty przygotowal. Tak, że w ludzie przybranym przez Boga, który w całości jest kapłański i królewski, namaszczenie otrzymuje nie przywilej ziemskiego pochodzenia, ale przychylność niebieskiej laski rodzi biskupa" ${ }^{38}$.

${ }^{34}$ Sermo 95, 1, SCh 200, 266: „Et quid tam sacerdotale quam vovere Domino conscientiam puram, et immaculatas pietatis hostias de altari cordis offerre". Według niektórych komentatorów "immaculata hostia" to aluzja do „spiritales hostias”, o których jest mowa w 1 P 2, 5 .

${ }^{35}$ Por. Sermo 32, 2, SCh 49 bis, 14.

${ }^{36}$ Sermo 95, 1, SCh 200, 266: „sacramentum, quod, effuso benedictionis unguento, copiosius quidem in superiora profluxit, sed non parce etiam in inferiora descendit". Francuski edytor dostrzega w tym miejscu aluzje do namaszczenia, glowy i szat, o którym jest mowa w Ps 132, 2.

${ }^{37}$ Św. Leon Wielki wyraźnie zauważa, że urząd kapłański, w którym uczestniczą wierni istnieje „praeter istam specialem nostri ministerii servitutem” (Sermo 95, 1, SCh 200, 266). W tłumaczeniu K. Tomczaka ten fragment zostal pominięty, por. Mowa 4, 1, POK 24, 12.

${ }^{38}$ Sermo 94, 1, SCh 200, 256: „divini sacerdotii sacramentum etiam ad humanas pervenit functiones, non per generationum tramitem curritur, nec quod caro et sanguis creavit [...] eos rectores Ecclesia accipit, quod Spiritus sanctus praeparavit; ut in populo adoptionis Dei, cujus universitas sacerdotalis atque regalis est, non praerogativa terrenae originis obtineat unctionem, sed dignatio caelestis gratiae gignat antistitem". 
Innymi slowy, różnica między ogólem wiernych, a tymi, którzy stanowią „wyższą" część „ciała Kościoła”, nie jest pochodną miejsca, jakie jedni i drudzy zajmują w „ciele Chrystusa”, ani władzy, jaką ci ostatni sprawują, ale ma ona charakter ontyczny ${ }^{39}$. To ten charakter właśnie skutkuje i miejscem i funkcjami, jakie poszczególni członkowie Kościoła pełnią. Wszyscy uczestniczą w kapłaństwie Chrystusa na mocy chrztu, ale istnieje też specjalne „ordo sacerdotis"40, w któryn uczestniczą już tylko niektórzy. Wchodzi się do niego w „dniu przyjęcia boskiego daru kapłaństwa" ${ }^{41}$. Trzeba przy tym pamiętać, że „ordo sacerdotalis" też nie jest jednolite. $\mathrm{Z}$ całą pewnością istnieją w nim „najwyżsi przełożeni” oraz „kapłani drugiego stopnia”, czyli „szafarze sakramentów”42. To zróżnicowanie jest mało przejrzyste, bo nawet terminologia jasno go nie wyraża ${ }^{43}$ Generalnie rzecz biorąc, są to „kapłani” i ,pasterze” ${ }^{44}$, kierujący Kościołem i spełniający „posługę sakramentów”,45.

3. Laikat $\mathbf{i}$ duchowieństwo. Kościół jaki wyłania się z Mów św. Leona Wielkiego, jest dobrze hierarchicznie zorganizowany i ma jasną strukturę. W tej strukturze jest miejsce dla duchownych oraz dla świeckich, choć o roli, jaką jedni i drudzy winni odgrywać, nasz Papież wypowiada się w sposób dość oględny. Jak już zostało powiedziane, z samych mów możemy się domyśleć, że wierni świeccy stanowią te niższe partie ciała Chrystusa, na które namaszczenie kapłańskie spłynęło nie tak obficie, jak na „ordo sacerdotalis". Stanowią oni "owczarnię"46, której przewodzi biskup ${ }^{47}$ kierujący się "pasterską troską" (sollicitudo pastoralis) ${ }^{48}$. Jest on zatroskany o ,zbawienie dusz" ${ }^{49}$ powierzonych mu owiec, bo $\mathrm{z}$ tego zda kiedyś rachunek ${ }^{50}$. Natomiast owce winna

${ }^{39}$ W Mowach Leona nie zostało wyjaśnione, czy istnieje jakies specjalne „namaszczenie” dla przynależących do „ordo sacerdotalis". Wprawdzie jest mowa o "unctio sacerdotum" (Sermo 46,7, SCh 74, 61) oraz "consecratio sacerdotum" (Sermo 53, 2, SCh 74, 96; 95, 1, SCh 200, 266), ale, jak się okazuje, oba te określenia występują zamiennie.

40 Por. Sermo 72, 2, SCh 200, 72.

${ }^{41}$ Św. Leon Wielki wspominając dzień objęcia biskupstwa mówi, że świętuje „suscepti sacer. dotii diem divini muneris" (Sermo 96, 4, SCh 200, 282).

${ }^{42}$ Por. Sermo 35, 1, SCh 49bis, 170: „summi antistites [...] secundi ordini sacerdotes [...] ministri sacramentorum".

${ }^{43}$ W Mowach terminy: „sacerdos”, ,minister” są używane mało precyzyjnie.

44 Por. Sermo 95, 3, SCh 200, 268: „sacerdoti et pastores".

${ }^{45}$ Leon Wielki wspomina „,antistites”, „rectores”, „principes Ecclesiae”. Natomiast „ministerium sacramentorum" wypełniał według niego także diakon Wawrzyniec (Sermo 72, 2, SCh 200, 74), trudno więc określić, o jakie to dokladnie funkcje chodzi.

${ }^{46}$ Por. Sermo 94, 4, SCh 200, 262: „grex Domini”, zob. również Sermo 96, 2, SCh 200, 280.

47 Biskupi to „pastores qui gregibus suis praesint” (Sermo 96, 2, SCh 200, 278). Por. tez Sermo 96,5 , SCh 200, 284; 94, 4, SCh 200, 260.

${ }^{48} \mathrm{O}$ ożywiającej go "sollicitudine pastorali” Leon Wielki wzmiankuje wielokrotnie, por. Sermo 92, SCh 200, 246; 62, 5, SCh 74, 148; 96, 2, SCh 200, 278. Rzeczą drugorzędną w tym przypadku jest to, że zdaniem Papieża jego zadania są większe od zadań innych biskupów, gdyż 


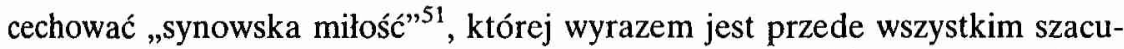
nek dla duszpasterskich poleceń pasterza. Z tonu, w jakim przemawial św. Leon Wielki można wnioskować, że spodziewa się respektowania jego moralnych i ascetycznych zaleceń. Swoje kazania kieruje przede wszystkim do świeckich, choć czasem wśród słuchaczy dostrzega duchownych ${ }^{52}$. Zastosowania moralne, jakie wskazuje zdają się jednak uwzględniać tylko świeckich.

Pasterze i wierni mają swoje obowiązki, które w Mowach są tylko ogólnie wzmiankowane. Obowiązki duchownych wyrażają się w ich pracy duszpasterskiej. Najogólniej rzecz biorąc „obowiązkiem kapłana jest wspólna troska o wszystkie dzieci Kościoła w tym, co pomaga zarówno prostym jak też wyksztalconym" "53. Tę troskę wypełnia, jak się wydaje przede wszystkim przez posługę słowa (officium sermonis) ${ }^{54}$ oraz posługę tajemnicom (ministerium sacramentorum $)^{55}$. O ile ta pierwsza posługa jest $w$ miarę jasno zdefiniowana, to w przypadku drugiej należy się domyślać dość szerokiego znaczenia tego określenia. Skoro bowiem $w$ tę posługę jest zaangażowany diakon - a konkretnie Wawrzyniec - to z całą pewnością nie można jej zacieśnić do sprawowania Eucharystii czy też innych sakramentów ${ }^{56}$. Do tych obowiązków z całą pewnością należy dodać te, jakie mieli zwłaszcza biskupi, jako kierujący Kościolem. Mieli oni również „władzę związywania i rozwiązywania”, wych wskazań związanych $\mathrm{z}$ jej sprawowaniem Leon Wielki nie podaje.

Generalnie rzecz ujmując można przyjąć, że w Kościele, jaki wyłania się $z$ mów papieża Leona Wielkiego, duchownych od świeckich różni stopień (gradus) kapłaństwa oraz wynikające $z$ tego obowiązki. Stanowią wspólnie cialo Chrystusa, ale pełnią w nim różne funkcje, bardzo jasno rozgraniczone. Zarówno duchowni, jak też świeccy, mają wspólnie dążyć do świętości. Co do tego nie ma żadnej wątpliwości. O ile jednak świętość duchownych jest mało zdefiniowana, to świeccy otrzymują w mowach w miarę szczegółowe wskazówki. Dotyczą one obowiązków moralnych i ascetycznych.

„nobis tamen cum omnibus cura communis est; neque cuiusquam administratio, non nostri laboris est portio" (Sermo 96, 2, SCh 200, 278).

49 Por. Sermo 92, 1, SCh 200, 246: ,animarum vestrarum salutem”.

${ }^{50}$ Por. Sermo 96, 2, SCh 200, 278: „Pastores [...] sciant se pro commissis sibi ovibus reddituros esse rationem".

${ }^{51}$ Por. Sermo 96, 5, SCh 200, 284: „pietas filiorum”.

$52 \mathrm{~W}$ jednym $\mathrm{z}$ kazań cieszy się „cumque hanc venerabilium consacerdotum meorum splendidissimam frequentiam frequentiam video" (Sermo 93, 2, SCh 200, 250).

53 Sermo 81, 1, SCh 200, 142-144: „sacerdotalis officii est erga omnes Ecclesiae filios curam habere communem, in id quod et rudibus prosit et doctis".

${ }^{54}$ Por. Sermo 59, 1, SCh 74, 129; 89, 1, SCh 200, 208.

${ }^{55}$ Por. Sermo 72, 2, SCh 200, 74. Kiedy indziej zaś kaplanów nazwie „ministri sacramentorum" (Sermo 35, 1, SCh 49bis, 170).

${ }_{56}$ Por. Sermo 72, 2, SCh 200, 74.

57 Por. Sermo 96, 5, SCh 200, 284: „ius ligandi atque solvendi”. 
Ze specyficznych obowiązków związanych z życiem wspólnoty Leon Wielki wymienia tylko kilka. Jednym z najważniejszych, jak się wydaje, jest wpływ na wybór biskupa. W swej mowie po wyborze na papieża dziękuje za „laskawość", jakiej doświadczył ze strony słuchaczy, którzy „wyrazili o nim tak święty sąd, bez żadnych jego wcześniejszych zasług" ${ }^{\text {" }}$. Chociaż jest to niewątpliwa aluzja do jakieś procedury wyborczej, to nie sposób nic bardziej szczegółowego na ten temat powiedzieć. Nie znamy ani procedur rządzących wyborami, ani też rzeczywistego w nich udziału wiernych ${ }^{59}$. Wybór ten jest dla św. Leona Wielkiego zobowiązujący. Wyraża zatem gotowość gorliwej pracy duszpasterskiej dla „zbawienia ich dusz ${ }^{\prime 60}$. Jednocześnie jednak zobowiązuje ich do modlitwy w swej intencji, aby otrzymał wystarczające wsparcie Ducha Świętego, potrzebne do dobrego sprawowania powierzonego mu urzędu ${ }^{61}$.

Wiernym rzymskim przypomina też ich biskup o jeszcze jednym obowiąz$\mathrm{ku}$. Wobec zagrożenia wynikającego z napływu do Rzymu różnej maści heretyków - a zwłaszcza manichejczyków - wierni mają wykazać nie tylko daleko idącą ostrożność, ale pomóc biskupowi w ich zidentyfikowaniu. Biskup mówi im wprost:

„Najmilsi, proszę was o to usilnie i napominam, aby gdy ktoś z was dowie się, gdzie [oni] mieszkają i nauczają, kogo odwiedzają i w jakim towarzystwie znajdują pocieszenie, niech uczciwie nas o tym powiadomi" ${ }^{\text {62 }}$.

Celem tej identyfikacji ma być w pierwszym rzędzie wykluczenie ich ze wspólnoty, co jest obowiązkiem biskupa ${ }^{63}$. Mobilizacja wiernych ma też uniemożliwić osiedlenie się na stałe tych ludzi w Rzymie ${ }^{64}$. Obowiązek denuncjowania heretyków ma być wyrazem odpowiedzialności za przekaz Dobrej Nowiny, a także poważnego potraktowania spraw swej wiary.

Gmina rzymska za czasów pontyfikatu św. Leona Wielkiego miała dobrze uksztaltowane struktury, jasny podział obowiązków i praw. W sposób widzialny dzieliła się na Kościół nauczający i słuchający. Ten drugi stanowili wierni uczestniczący w nabożeństwach w kościele św. Piotra. Kierowanie życiem wspólnoty i decydujący głos miał przede wszystkim biskup, wspierany w działalności duszpasterskiej przez podległe mu duchowieństwo. Wierni byli kon-

${ }^{58}$ Por. Sermo 92, 1, SCh 200, 246: „qui tam sanctam de me, nullis admodum praecedentibus meritis, judicium protulistis".

59 Uwaga K. Tomczaka (POK 24, 3), że w tej mowie chodzi przede wszystkim o duchowieństwo, nie wydaje się całkiem przekonywująca.

${ }^{60}$ Por. Sermo 92, 1, SCh 200, 246: „animarum vestrarum salutem pastorali sollicitudine”.

61 Por. Sermo 92, SCh 200, 246.

62 Sermo 86, 5, SCh 200, 186: „dilectissimi, obsecrans moneo, ut si cui vestrum innotuerit ubi habitant, ubi doceant, quos frequentant, et in quorum societate requiescant, nostrae sollicitudini fideliter indicets". Por. też Sermo 23, 4, SCh 49 bis, 46.

63 Por. Sermo 29, 5, SCh 49bis, 112.

64 Por. Sermo 23, 4, SCh 49bis, 46. 
sultowani w szczególnych momentach życia wspólnoty, ale na co dzień wystarczyło, że uczestniczyli w życiu religijnym, wypełniali uczynki miłosierne i starali się o osobisty wzrost duchowy. W jaki sposób mają to czynić, słyszeli od biskupa.

\section{LAICI NELLA LUCE DEI SERMONES DI LEONE MAGNO}

\section{(Riassunto)}

Dai Sermoni di Leone Magno risulta che la Chiesa di Roma d'allora era ben organizzata ed aveva una struttura già stabilita. La chiara distinzione tra „ordo sacerdotis” e il resto dei "membra Christi” destinava i rispettivi doveri. I laici erano ben consapevoli della sua partecipazione al „corpo di Cristo” e d'essere un „reale sacerdozio", ma il loro influsso sulla vita della comunità era assai scarsa. 